\title{
ANALISIS PENGELOLAAN CABANG BANK; DARI MANA BANK MERAIH PROFIT?
}

\author{
Iman Sidik Nusannas. SS., ME \\ Program Studi Manajemen - STIE Dr KHEZ Muttaqien \\ Jl. K.K Singawinata No 83 Purwakarta
}

\begin{abstract}
Banking management, as also enterprise management is always an interested topic to discuss, since the goal of bank as also enterprise is to reach the profit. Profit can be gained from three main bank activities ie; Funding Lending and services. Three acvtities will earn profit with a proper manner to manage. From lending and Funding a bank can gain spread based income and from services bank can gain fee based income.This journal is to look up those three bank activities.

Keywords: Bank, Funding, Lending, Services.
\end{abstract}

\section{Pendahuluan}

Fungsi bank menurut UU Perbankan adalah Funding, Lending, dan Service. Ketiga fungsi ini saling mensupport untuk menciptakan profit dan benefit . Profit adalah

\section{Tinjauan Teoritis}

\section{Funding}

Terdapat tiga produk bank yang mewakili funding, yaitu tabungan giro dan deposito. Ketiga produk ini

\section{Tabungan}

Menurut UU perbankan No. 10 Tahun 1998 atas undang-undang No.7 tahun 1992 tentang perbankan pada pasal 1 ayat 9 disebutkan bahwa tabungan adalah "simpanan yang pada penarikannya hanya dapat di lakukan menurut syarat tertentu yang telah di sepakati, namun tidak keuntungan yang diperoleh oleh bank sedangkan benefit adalah keuntungan non material yang diterima bank dan atau nasabah.

sudah lama dikenal di masyarakat dan dipakai dalam bertransaksi sehari-hari di bank.

dapat di tarik dengan cek, bilyet giro atau alat lainnya di persamakan dengan itu."

Tabungan merupakan simpanan masyarakat yang penarikannya dapat dilakukan oleh nasabah penabung kapanpun. Tabungan merupakan 
hutang bank kepada masyarakat, dalam hal ini pemilik tabungan, dikelompokkan kedalam hutang jangka pendek dalam neraca. Tidak adanya batasan jangka waktu tabungan dan penarikan yang dapat dilakukan sewaktu-waktu menyebabkan tabungan harus digolongkan ke dalam hutang jangka pendek.

\section{Giro}

Giro adalah simpanan nasabah yang penarikannya dapat dilakukan setiap saat dengan menggunakan cek, surat perintah pembayaran lainnya atau dengan cara pemindahbukuan. Bank menetapkan harga dana giro lebih rendah karena lama pengendapannya tidak dapat dipastikan secara tepat, dimana pemilik rekening giro dapat menarik uangnya kapan saja mereka kehendaki.

Penarikan dana giro oleh si pemilik hanya dapat dilakukan dengan cara perintah tertulis dari si pemiliknya

\section{Penarikan dengan warkat}

a) Cek

Yaitu "Surat perintah tanpa syarat dari nasabah pemilik rekening kepada bank dimana rekening giro nasabah tersebut dikelola, untuk membayar sejumlah uang kepada pihak yang disebut di dalamnya atau kepada pemegang cek tersebut".Macam-macam cek,diantaranya :

1) Cek atas nama

Cek yang diterbitkan atas nama seseorang atau badan hukum tertentu yang tertulis jelas di dalam cek tersebut.

2) Cek atas unjuk
Setiap bank memiliki jenis tabungan yang berbeda-beda. Perhitungan suku bunga, pemberian hadiah, tata cara setor dan tarik juga berbeda bagi setiap bank. Produk tabungan ini dapat dijadikan alat promosi bagi yang menawarkannya. Promosi dapat disalurkan dalam bentuk suku bunga, hadiah yang menarik, kemudahan fasilitas dan lain sebagainya.

sebagai dasar resmi otorisasi pendebetan rekening nasabah oleh bank. Penarikan ini dapat dilakukan sewaktu-waktu nasabah menghendakinya, bank akan memeriksa kebenaran nomor rekening, tanda tangan, kecukupan saldo dan informasi lainnya yang diperlukan. seiring perkembangan jaman, rekening giro dapat ditarik melalui ATM, atau delivery channel bank lainnya semisal internet banking dan Mobile banking.

Kebalikan dari cek atas nama. Di dalam cek tidak tertulis nama seseorang atau badan hukum.

3) Cek silang

Cek yang dipojok kiri diberi dua garis sejajar, sehingga cek tersebut tidak dapat ditarik tunai melainkan pemindahbukuan.

4) Cek mundur

Cek yang diberi tanggal mundur dari tanggal. Hal ini biasanya terjadi karena kesepakatan antara pemberi dan penerima cek. 
5) Cek kosong Atau blank cheque

Merupakan cek yang penarikkannya melebihi saldo yang ada.

b) Bilyet Giro

Yaitu "Surat perintah dari nasabah kepada bank yang memelihara giro nasabah tersebut, untuk memindahbukukan sejumlah uang dari rekening yang bersangkutan kepada pihak penerima yang disebutkan namanya atau nomor rekening pada bank yang sama atau bank lainnya".

Syarat-syarat yang berlaku untuk BG agar pemindahbukuannya dapat dilakukan antara lain :

1) pada surat cek tertulis perkataan "Bilyet Giro" dan nomor seri

2) surat harus berisi perintah tak bersyarat untuk memindahbukukan sejumlah uang tertentu atas beban rekening yang bersangkutan

\section{Deposito}

Menurut Lukman Dendawijaya dalam bukunya "Manajemen Perbankan" : Deposito adalah simpanan dari pihak ketiga kepada bank yang penarikannya hanya dapat dilakukan dalam jangka waktu tertentu menurut perjanjian antara pihak ketiga dengan bank yang bersangkutan “. (2001;27) Pengertian deposito berjangka menurut Y.Sri Susilo, Sigit Trinu, A. Totok Budi Santoso. Dalam bukunya "Bank dan lembaga keuangan lain"; “ Deposito berjangka adalah simpanan yang penarikannya hanya dapat dilakukan pada waktu tertentu sesuai tanggal yang diperjanjikan
3) nama bank yang harus membayar (tertarik)

4) nama penerima dana dan nomor rekening

5) nama bank penerima dana

6) jumlah dana dalam angka dan huruf

7) penyebutan tanggal dan tempat cek dikeluarkan

8) tanda tangan dan atau cap perusahaan.

Masa berlaku dan tanggal berlakunya BG juga diatur sesuai dengan persyaratan yang telah ditentukan seperti :

1) masa berlakunya adalah 70 hari terhitung mulai tanggal penarikannya

2) bila tanggal efektif tidak ada maka tanggal penarikan berlaku sebagai tanggal effektif

3) bila tanggal efektif tidak ada maka tanggal efektif berlaku sebagai tanggal penarikan

4) dan persyaratan lainnya.

antara deposan dengan bank “. (2000;63)

Menurut Drs.O.P Simorangkir, dalam bukunya "Pengantar Lembaga Keuangan Bank dan Non Bank" Deposito adalah Simpanan dalam rupiah milik pihak ketiga yang penarikannya dilakukan setelah jangka waktu tertentu menurut perjanjian antara bank dengan si penyimpan $(2000 ; 80)$

Dari definisi diatas dapat diambil kesimpulan bahwa bila waktu yang ditentukan telah habis maka pihak deposan dapat melakukan :

a. Menarik deposito tersebut

b. Memperpanjang dengan suatu periode yang di inginkan 
jangkah waktu deposito dapat dipilih sesuai dengan kebutuhan

\section{Jenis-Jenis Deposito}

Deposito dapat dikelompokan dalam beberapa jenis diantaranya :

a) Deposito Berjangka

Yaitu simpanan yang memiliki jangka waktu tertentu dengan tingkat suku bunga tertentu pula, deposito ini hanya dapat ditarik apabila telah jatuh tempo.

b) Sertifikat Deposito

Yaitu simpanan berjangka atas bawa atau atas unjuk yang diizin bank indonesia dikeluarka oleh bank sebagai bukti simpanan yang dapat diperjual belikan atau pindah tangankan.

c) Deposit On Call

Yaitu jenis deposito berjangka yang pada saat penarikannya

\section{Lending \\ Kredit Umum \\ Kredit Lokal}

Kredit lokal atau dikenal pula dengan kredit rekening koran adalah pinjaman revolving jangka waktu (satu tahun) yang penarikannya dapat dilakukan setiap saat tanpa pemberitahuan terlebih dahulu kepada pihak bank dengan mempergunakan cek, bilyet giro atau alat perintah pembayaran lainnya. Tujuan kredit rekening koran adalah untuk membiayai modal kerja.

Perhitungan bunga dilakukan secaha harian berdasarkan saldo akhir bulan, total bunga selama satu bulan akan dibayar pada akhir bulan.

Rumus Bunga $=\underline{\text { saldo } \mathrm{x} \text { rate }}$

360

Keterangan : yaitu: 1 bulan, 3 bulan, 6 bulan, 12 bulan dan 24 bulan.

harus diberitahukan paling lambat satu bulan sebelum jatuh tempo.

d) Deposito Automatic Roll Over Merupakan simpanan deposito yang apabila telah jatuh tempo dapat diperpanjang secara otomatis oleh pihak bank beserta perhitungan bunganya.

e) Deposito Kena Finalty (Finalty Rate)

Deposito yang ditarik atau diambil oleh pemiliknya (nasabah) sebelum jatuh tempo sehingga bank akan mengenakan denda sesuai dengan kebijaksanaan manajemen yang diberiakn kepada nasabahnya.

bunga : bunga pinjaman yang dibayar pada tanggal tertentu saldo : saldo debet (o/s) tanggal yang bersangkutan rate : suku bunga per tahun

Kredit dapat menciptakan alat pembayaran baru, maksudnya adalah salah satu jenis kredit yang diberikan oleh bank umum yaitu rekening koran. Dalam kredit rekening koran, begitu perjanjian kredit ditandatangani dan syarat-syarat kredit teleh terpenuhi maka pada dasarnya pada saat itu teleh beredar uang giral baru di masyarakat sejumlah kredit rekening koran tersebut. 
Jenis-Jenis Kredit Lokal ( Kredit Rekening Koran )

1) Kredit rekening koran bebas

Debitur menerima seluruh

kreditnya dalam bentuk

rekening koran dan

kepadanya diberikan blanko

cek dan rekening Koran

pinjamannya diisi menurut

besarnya kredit yang

diberikan. Debitur bebas

melakukan penarikan

kedalam rekening

bersangkutan selama kredit berjalan.

2) Kredit rekening koran terbatas

Dalam sistem ini terdapat suatu pembatasan tertentu bagi nasabah dalam melakukan penarikanpenarikan uang via rekeningnya.

3) Kredit rekening koran aflopend

Penarikan kredit dilakukan sekaligus dalam arti kata seluruh maksimum kredit pada waktu penarikan pertama telah sepenuhnya dipergunakan oleh nasabah.

\section{Prosedur Pemberian Kredit}

Secara umum prosedur kredit menurut Kasmir (2002:110) sebagai berikut

1) Pengajuan berkas-berkas Pengajuan proposal kredit hendaknya berisi antara lain :
a) Latar perusahaan
b) Maksud dan tujuan
c) Besarnya kredit dan jangka waktu
d) Cara pemohon mengembalikan kredit
e) Jaminan kredit

2) Penyelidikan berkas pinjaman
4) Revolving credit

Sistem penarikan kredit sama dengan cara redkening Koran bebas dengan masa penggunaanya 1 tahun. Akan tetapi cara pemakaiannya berbeda. Dalam cara pemakaiannya nasabah diperkenankan mendisposisi bebas akan tetapi diisyaratkan misalnya pada akhir triwulan I saldo pinjaman harus telah menunjukkan sisa 0 dan pada awal triwulan II nasabah dapat lagi melakukan penarikan bebas sampai akhir triwulan selanjutnya yang harus menunjukkan saldo nihil, demikian seterusnya sampai 1 tahun.

5) Term loan

Dalam term loan penggunaan dan pemakaian kredit sangat fleksibel artinya si nasabah bebas menggunakan uang kredit untuk keperluan apa saja dan bank tidak mau tau tentang itu.

Tujuannya adalah untuk mengetahiu apakah berkas yang diajukan sudah lengkap sesuai persyaratan dan sudah benar.

3) Wawancara I

Merupakan penyidikan kepada calon peminjam dengan langsung berhadapan dengan calon peminjam, untuk meyakinkan apakah berkas-berkas tersebut sesuai dengan lengkap seperti dengan yang bank inginkan.

4) On The Spot 
Merupakan kegiatan pemeriksaan ke lapangan dengan meninjau berbagai objek yang akan dijadikan usaha atau jaminan.

5) Wawancara ke II

Merupakan kegiatan perbaikan berkas, jika mungkin ada kekurangankekurangan pada saat setelah dilakukan on the spot di lapangan.

6) Keputusan Kredit

Keputusan kredit dalam hal ini adalah menentukan apakah kredit akan diberikan atau ditolak.

7) Pentanganan akad kredit/perjanjian lainnya

Kegiatan ini merupakan kelanjutan dari diputuskannya kredit, maka sebelum kredit

\section{Time Loan}

Time Loan adalah bentuk fasilitas kredit yang cara penarikan dananya dapat dilakukan sekaligus seluruhnya atau bertahap sesuai dengan kebutuhan debitur dengan menarik surat aksep, kemudian dapat dibayar kembali sesuai kehendak debitur atau pada saat jatuh tempo.

\section{Trust receipt}

Trust receipt adalah fasilitas kredit modal kerja yang diberikan kepada debitur importir untuk pembayaran atau pelunasan L/C Sight atau SKBDN atas unjuk yang diterbitkan melalui lembaga perbankan dengan

\section{Kredit Ekspor}

Kredit Ekspor atau export loan yaitu kredit untuk membiayai kegiatan investasi dari modal kerja yang diberikan dalam rupiah dan/atau valuta asing kepada eksportir atau dicairkan, calon nasabah mentangani akad kredit, mengikat jaminan dengan hipotik dan surat perjanjian atau pernyataan dianggap perlu.

8) Realisasi kredit

Realisasi kredit diberikan setelah pentanganan suratsurat yang diperlukan dengan membuka rekening giro atau tabungan di bank yang bersangkutan.

9) Penyaluran atau penarikan dana

Adalah pencarian atau pengambilan uang dari rekening sebagai realisasi dari pemberian kredit dan dapat diambil sesuai ketentuan dan tujuan kredit yaitu sekaligus atau secara bertahap.

sumber dana dari lembaga perbankan tersebut. Deskripsi umum tentang Trust receipt biasanya adalah :

a. Jenis Transaksinya Import/ lokal

b. Jenis fasilitas Short Term Cash Loan

c. Struktur fasilitasnya L/ C atau SKBDN Sub Limit T/ R

d. Mata Uang umumnya USD atau IDR

e. Penggunaan Dana untuk pelunasan L/ C Sight atau SKBDN

f. atas unjuk

g. Sarana Pencairannya Promes

h. Besar pencairan dana maks 100 $\%$ dari L/ C atau SKBDN

pemasok. Dalam rangka mendorong produksi komoditi ekspor, pemerintah biasanya memberikan bermacam-macam

fasilitas.penunjang agar kegiatan 
ekspor kita dapat berkembang, biasanya dalam hal pembiayaan. Salah satu contoh fasilitas yang diberikan pemerintah adalah kredit ekspor dengan bunga yang rendah, dibandingkan dengan kredit biasa.

Kredit ekspor yang ada di Indonesia adalah kredit modal kerja (working capital) yang diberikan bank pemerintah kepada eksportir untuk membiayai:

a. Usaha pengumpulan barang ekspor (collecting) hingga barang itu siap ekspor.

b. Memproduksi barang yang dimaksudkan untuk ekspor

c. Sebagai modal kerja selama masa tenggang antara tanggal pengapalan dengan waktu akseptasi wesel berjangka atau dibayarnya weseldi luar negeri.

\section{Jenis kredit ekspor}

Dalam rangka mendorong ekspor, pemerintah juga mengadalan program pertanggungan atau asuransi terhadap barang-barang ekspor. Bentuk pertanggungan atau asuransi yang dimaksud adalah jaminan kredit ekspor dan asuransi ekspor.

Jaminan kredit ekspor pada pokoknya menjamin pelunasan kredit bila eksportir menjalani kesulitankesulitan. Sedangkan asuransi ekspor pada pokoknya menjamin bahwa eksportir akan memperoleh pembayaran bilamana pembeli di luar negri mengingkari pembayaran atau bila pembayaran oleh pembeli di

\section{Installment loan}

Kredit cicilan (installment loan) adalah jumlah uang yang dipinjam untuk membeli barang seperti rumah atau mobil dan dikembalikan secara mencicil. Masa cicilan biasanya dihitung dalam bulan, seperti
Pertimbangan utama yang di lakukan bank dalam permohonan kredit ekspor oleh eksportir antara lain :

a. Persediaan barang untuk diekspor.

b. Irrevocable $\mathrm{L} / \mathrm{C}$ dari pembeli (importir) di luar negri.

c. Perjanjian jual beli dengan importir di luar negri yang tidak dapat dibatalkan sepihak.

d. Rencana produksi untuk menghasilkan barang ekspor atau bahan untuk diolah menjadi barang ekspor yang didukung oleh irrevocable $\mathrm{L} / \mathrm{C}$ dan atau perjanjian jual beli yang sudah dimiliki eksportir lain atau rencana produksi barang ekspor untuk konsinyasi.

luar negri tidak ditransfer ke Indonesia.

Secara umum dapat disimpulkan bahwa yang dimaksud dengan :

a. Jaminan Kredit Ekspor adalah sarana yang disediakan pemerintah untuk menutup pertanggungan atas resiko kemacetan kredit yang mungkin dihadapi oleh bank dalam memberikan kredit ekspor.

b. Asuransi Ekspor adalah sarana yang disediakan pemerintah untuk menutup pertanggungan atas resiko kurang atau tidak adanya pembayaran di luar negri yang mungkin dihadapi eksportir.

pinjaman 36 bulan untuk membeli mobil. Semakin lama jangka waktu pembayaran, semakin kecil cicilan bulanan tetapi semakin besar total biaya bunga. 


\section{L/C (Letter of Credit)}

L/C adalah surat jaminan yang dikeluarkan oleh bank yang menyatakan kepastian pembayran

\section{Service}

\section{Bank Notes dan TC}

\section{Bank Notes}

Merupakan uang kartal asing yang dikeluarkan dan diterbitkan oleh bank di luar negeri. Bank notes dikenal juga dengan istilah "devisa tunai" yang mempunyai sifat-sifat seperti uang tunai . Tidak semua bank notes dapat diperjualbelikan, hal ini tergantung daripada peraturan devisa di negara yang asal bank notes .

Sedangkan yang dimaksud dengan jual beli bank notes merupakan transaksi antara valuta yang dapat diterima pembayarannya dan dapat diperjualbelikan dan diperdagangkan kembali sesuai dengan nilai tukar yang terjadi pada saat itu .

Dalam transaksi jual beli bank notes, bank mengelompokkan bank notes ke dalam dua klasifikasi . Yaitu bank notes yang lemah dan bank notes yang kuat dan bank biasanya lebih menyukai bank notes yang nilainya kuat .

\section{Traveller's cheque/TC}

Traveller's cheque (TC) atau Cek Pelawat adalah cek yang diterbitkan oleh Bank dengan nominal yang telah ditetapkan. Denominasi yang diterbitkan biasanya 20, 50 dan 100 dalam mata uang U.S. dollars, Canadian dollars, pounds sterling, Japanese yen, dan euro. Bank menjual TC dalam paket yang terdiri dari 5 lembar atau 10 lembar TC. Masa berlaku TC tidak ada, sehingga kepda pihak tertentu, bilamana persyaratan yang tertuamg dalam $\mathrm{L} / \mathrm{C}$ telah dipenuhi.

Pengelompokkan bank notes yang kuat berdasarkan kategori sebagai berikut :

a. Bank notes tersebut mudah diperjualbelikan

b. Nilai tukar terkendali/stabil

c. Frekuensi penjualan sering terjadi

d. Dan pertimbangan lainnya Sedangkan kelompok bank notes yang lemah kebalikan dari bank notes yang kuat, dalam pengelompokkan ini tergantung dari bank yang bersangkutan.Dalam praktiknya bank tidak selalu menerima penjualan dan pembelian bank notes. Hal ini disebabkan oleh beberapa alasan yaitu :
a. Kondisi bank notes cacat/rusak
b. Tergolong dalam valuta lemah
c. Tidak memiliki persediaan
d. Diragukan keabsahannya

pemilik TC dapat kapan saja menggunakannya. Penggunaan TC sering dimanfaatkan oleh para pelancong ke luar negeri karena sifatnya yang lebih simple dibandingkan membawa fisik uang karena jika TC hilang dalam perjalanan, pemegang TC dapat melaporkan dan meminta penggantinya (refund) kepada bank ditempat kehilangan. 
Terminologi para pihak dalam transaksi TC yang perlu kita ketahui adalah:

a. Issuer/obligor, adalah institusi atau lembaga yang menerbitkan TC,biasanya Bank.

b. Agent, adalah institusi atau lembaga yang bertindak sebagai penjual, bisa dilakukan oleh Bank, atau lembaga-lembaga yang ditunjuk oleh Issuer.

c. Purchaser/Pembeli, adalah perorangan yang membeli TC ini dari agent.

d. Payee/Penerima, adalah pihak yang menerima TC dari purchaser/pembeli sebagai pembayaran transaksi yang diterima.

\section{Inkaso dan Collection}

\section{Inkaso}

Inkaso merupakan pemberian kuasa pada bank oleh perusahaan/perorangan untuk menagihkan, atau memintakan persetujuan pembayaran (akseptasi) atau menyerahkan begitu saja kepada pihak yang bersangkutan (tertarik) di tempat lain (dalam/luar negeri) atas surat-surat berharga, dalam rupiah atau valuta asing seperti wesel (draft), cek, kuitansi, surat aksep(promissory notes), dan lain-lain.

Pengertian inkaso menurut Lukman Dendawijaya dalam bukunya yang berjudul Manajemen Perbankan (2001:29) "Inkaso adalah jasa yang diberikan bank atas permintaan nasabah untuk menagihkan pembayaran surat-surat atau dokumen berharga kepada pihak ketiga ditempat lain dimana bank yang bersangkutan mempunyai cabang atau pada bank lain".

Warkat-Warkat Yang Digunakan Dalam Inkasso :
a. Cek
b. Bilyet Giro
c. Wesel
d. Kuitansi
e. Surat Aksep
f. Deviden
g. Kupon

\section{Collection (Inkaso Valuta Asing)}

Layanan Bank dalam rangka penagihan pembayaran atas warkat-warkat yang Bank tertariknya berada di Luar Negeri atau di Dalam Negeri namun Valuta Warkat dalam Valuta Asing.

\section{a. Keuntungan :}

Kemudahan dalam penagihan pembayaran warkat dalam valuta asing dengan biaya yang kompetitif.

\section{b. Manfaat}

Nasabah dapat menerima pembayaran warkat dari seluruh wilayah Indonesia dan dari negara tertentu sesuai ketentuan Bank Nasabah tidak perlu melakukan penagihan sendiri 
Bank Draft

Bank Draft (Cashier Check) sebenarnya adalah cek yang diterbitkan oleh Bank. Penjual sering meminta Bank Draft kepada calon pembeli untuk perjanjian awal pada transaksi nominal besar, misalnya transaksi pembelian mobil dan rumah. Hal ini memberikan rasa aman kepada penjual bahwa calon pembeli benar-benar memiliki uang untuk membayar dan tidak memberikan cek kosong. Kenapa tidak mungkin cek kosong? Karena Bank hanya mau menerbitkan Bank Draft ketika yang nasabahnya benarbenar memiliki uang sebesar nilai Bank Draft yang akan diterbitkan. Bank akan meminta nasabahnya untuk mengisi formulir aplikasi dan menetapkan tarif untuk penerbitan Bank Draft tersebut. Selanjutnya, Bank juga akan mendebet secara langsung rekening nasabah sebelum memberikan Bank Draft tersebut kepada nasabahnya.

Sebuah Bank Draft memiliki ciri antara lain:

\section{Kiriman Uang}

Transfer merupakan jasa pengiriman uang lewat bank baik dalam kota, luar kota atau keluar negeri. Lama pengiriman tergantung dari sarana yang digunakan untuk mengirim. Sebagai contoh jika Tn. Aldi bermaksud mengirim uang buat ibunya di Solo lewat BBD Jakarta, maka Tn. Aldi dapat memilih sarana pengiriman yang diinginkan, apakah lewat telex atau telepon. Kecepatan pengiriman juga tergantung sarana yang digunakan, misalnya pengiriman lewat telepon jauh lebih cepat dibandingkan lewat telex . a. Diterbitkan dalam nominal berapa pun

b. Terdapat 2 (dua) nama bank dan ttangan pejabat bank yang mengeluarkan

c. Terdapat nama orang yang menjadi penerima uang, bukan nama nasabah

d. Memiliki jangka waktu penggunaan

Untuk bisa menguangkan sebuah Bank Draft, maka penerima Bank Draft harus memperlakukannya seperti sebuah cek. Penerima Bank Draft harus selalu memastikan kepada Bank penerbit apakah Bank Draft ini asli atau tidak, sehingga ketika seorang pembeli menawarkan sebuah Bank Draft langkah yang paling aman jangan memberikan barang tersebut kepada calon pembeli sampai dapat dipastikan Bank Draft itu asli dan tentunya sudah mendapat pembayaran dari Bank.

Sarana yang digunakan dalam jasa transfer ini tergantung kemauan nasabah . sarana yang dipilih akan mempengaruhi kecepatan pengiriman dan besar kecilnya biaya pengiriman .

Sarana-sarana yang biasa digunakan adalah :

a. Surat

b. Telex

c. Telepon

d. Faksimile

e. On line komputer

f. Dan sarana lainnya 
Keuntungan yang diperoleh oleh masing-masing pihak antar lain :
a. Bagi nasabah akan mendapat
e. Prosedur mudah dan murah
b. Pengiriman uang lebih cepat
f. Bagi bank akan memperoleh
c. Aman sampai tujuan
d. Pengiriman dapat lewat telepon dilakukan
g. Biaya kirim
h. Biaya provinsi dan komisi
i. Pelayanan kepada nasabah pembebanan rekening

Ada 2 jenis transfer/kiriman uang ke Bank lain, yaitu;

\section{RTGS (real time gross settlement) \\ Adalah transfer ke Bank lain dari nominal Rp 1 s/d tak terbatas, yang waktu kirimnya sampai hari itu juga, (bisa sampai 1 s/d 5 jam). Biayanya sekitar 20 rb-50 ribu tergantung Banknya). Waktunya mulai jam buka Bank sampai 14.00 atau 15.00 (tergantung banknya).}

2. KLIRING LLG KREDIT

Adalah transfer ke Bank lain dari nominal $\mathrm{Rp} 1$ s/d $<\mathrm{Rp}$

\section{Safe Deposit Box}

Layanan Safe deposit box adalah jasa penyewaan kotak penyimpanan harta atau surat-surat berharga yang dirancang secara khusus dari bahan baja dan ditempatkan dalam ruang khasanah yang kokoh, tahan bongkar dan tahan api untuk memberikan rasa aman bagi penggunanya.

Kondisi ketidakpastian selalu menambah rasa khawatir, terutama menyangkut keamanan barangbarang yang tidak ternilai harganya. Dalam menentukan pilihan untuk

\section{Keuntungan yang didapatkan :}

a. Ruang penyimpanan yang kokoh dilengkapi dengan sistem keamanan terus menerus selama 24 jam
100.000.000, (Untuk nominal $\geq$ Rp100.000.000 tidak bisa menggunakan kliring LLG tapi harus memakai RTGS) yang waktu kirimnya sampai 1 hari sampai seminggu,( Biayanya sekitar 5ribu -15 ribu tergantung Banknya). Waktunya mulai jam buka Bank sampai tutup Layanan (tergantung banknya). Untuk layanan Kliring bisa juga lewat ATM , jadi tidak usah dateng ke Banknya, tapi syarat dan ketentuan berlaku.

tempat penyimpanan yang tepat, tentunya harus memilih tempat yang terpercaya.

Bank sebagai bank terbesar dan terpercaya sangat mengerti dan selalu memahami kebutuhan . Kami menawarkan jasa layanan Safe deposit box untuk tempat menyimpan barang berharga dengan jaminan keamanan dan layanan yang sempurna. pun bisa tidur dengan lebih

nyenyak

b. Tarif sewa yang kompetitif

c. Tersedia dalam berbagai ukuran sesuai dengan kebutuhan 


\section{Kliring}

Kliring adalah suatu tata cara perhitungan hutang piutang dalam bentuk surat-surat dagang dan surat berharga dari suatu bank terhadap bank lainnya dengan maksud agar penyelesaiannya mudah dan aman serta untuk memperlancar pembayaran giral.

Giral adalah simpanan dari pihak ketiga yang penarikannya dapat dilakukan setiap saat dengan cek, surat perintah pembayaran lainnya atau pemindahbukuan. Lalu lintas giral adalah proses kegiatan bayar membayar dengan warkat/nota kliring, yang dilakukan dengan cara saling memperhitungkan antar bank, baik atas beban maupun untuk keuntungan nasabah yang bersangkutan.

\section{Pembahasan}

Dari sumber dana tabungan dan giro, bank mendapat sumber dana murah karena biaya untuk mendapatkan dana tersebut lebih murah dari deposito. Dalam terminology perbankan sumber dana seperti ini disebut CASA (current account and saving account). CASA adalah sumber dana yang jika disalurkan melalui kredit akan mendapatkan margin yang cukup lebar.

Sedangkan dari sumber dana deposito bank mendapatkan dana yang lebih mahal dibandingkan dengan CASA, oleh karena itu dana deposito lazim disebut dana mahal, karena untuk mendapatkan dana tersebut bank harus mengeluarkan biaya yang lebih besar.

Seluruh dana yang terkumpul melalui tabungan giro dan deposito,
Kliring adalah salah satu cara penyelesaian utang piutang antar bank-bank peserta kliring yang berbentuk surat-surat berharga. Dalam dunia perbankan kliring menunjukan sebuah jalannya kegiatan hingga selesai setelah perjanjian misalnya sebuah transaksi. Kliring ini memastikan semuanya menjadi clear dan berjalan sesuai dengan aturan pasar, meskipun proses kliring dalam kesepakatan yang berjalan tidak berhasil diselesaikan oleh kedua belah pihak yakni penjual dan pembeli. Dalamproses kliring yang dilibatkan didalamnya antara lain adalah manajemen dari paska perdagangan dan pra ekposur kredit.

disebut Dana Pihak Ketiga (DPK). Dana inilah yang merupakan komponen penghitungan Loan to deposit ratio $(L D R)$ bagi sebuah bank.

DPK yang terkumpul dikonversi menjadi pinjaman (LOAN). Selisih/margin antara bunga dana yang dibayar ke nasabah dengan bunga pinjaman merupakan pendapatan bank yang dikenal dengan spread based income. Semakin besar DPK yang dihimpun, dan semakin besar dana yang disalurkan melalui kredit maka semakin besar pula spread based income yang diterima.

Selain funding dan lending, bank juga melengkapi layanan kepada nasabah dengan berbagai service. Dari berbagai service di atas bank 
menerima provisi, komisi dan biaya administrasi. Sebagai contoh jika sebuah bank memiliki rekening 1 juta nasabah dan setiap blan nasabah dikenakan biaya administrasi Rp. 20.000,- maka pendapatan dari biaya administrasi adalah 20 Milyar x 12 bulan $=240$ milyar per tahun. Semakin banyak nasabah yang

\section{Penutup}

Sebagai entitas usaha, bank menjalankan fungsi funding, lending dan service. Dari setiap fungsi tersebut jika dikelola dengan baik maka akan menghasilkan spread

\section{Daftar Pustaka}

Dendawijaya L, (2009) : Manajemen Perbankan: Jakarta: Ghalia Indonesia

\begin{tabular}{llll} 
Kasmir, & $(2010)$ & \multicolumn{2}{c}{ Manajemen } \\
Perbankan & Edisi Tiga, \\
Jakarta : PT Raja & PT \\
Grafindo Persada. &
\end{tabular}

Kasmir, (2009) Bank dan Lembaga Keauangan Lainnya dimiliki, maka semakin besar pendapatan yang diterima. Pendapatan dari service ini disebut Fee based Income.

Gabungan dari Spread based income dan Fee Based Income menjadikan bank bisa profit. Tentu saja profit akan semakin besar jika ditopang dengan biaya yang efisien.

based income dan fee based income yang menopang profit bank. Profit bank akan semakin baik jika disertai dengan efisiensi biaya dalam operasional bank.

Jakarta: PT Grafindo Persada.

$\begin{array}{rrr}\text { SimorangkirO.P (2004) } & \text { : Pengantar } \\ \text { Lembaga } & \text { Keuangan } \\ \text { Bank dan } & \text { Non Bank } \\ \text { Jakarta } & : & \text { Ghalia } \\ \text { Indonesia } & & \end{array}$

UU no 10, 1998

UU No 71992 